\title{
Sampah Pembawa Penyakit Bagi Masyarakat
}

\author{
Mukhammad Fakhrizal Baihaqi \\ IIK STRADA INDONESIA \\ baihaqifakhrizal@gmail.com
}

\begin{abstract}
Abstrak
Permasalahan sampah sudah sangat umum dimata masyarakat khususnya di daerah pinggiran kota atau di daerah perdesaan. Dari sampah tersebut menimbulakan masalah salah satunya banjir yang merebak menjadi penyakit dimana menimpa masyarakat. Mulai dari gatal-gatal, diare, dbd, dll. Sebaiknya kita sebagai warga negara Indonesia yang berbudi luhur seharusnya tidak membuang sampah disungai ataupun di pinggiran sungai agar disaat musim penghujan tidak terjadi banjir yang dapat menimbulkan penyakit. Solusi yang tepat untuk permasalahan sampah sendiri juga harus diperhatikan agar tepat dan masyarakat mendapat dampak baik dari solusi tersebut.
\end{abstract}

\section{Latar Belakang}

Tahun demi tahun sampah di bumi sering bertambah banyak. Dengan adanya sampah yang sering menumpuk ataupun dibuang di sembarang tempat dapat menimbulkan penyakit. Sumber dari beberapa penyakit adalah adanya sampah yang tidak benar benar diolah dengan baik hingga menyebabkan banjir. Sampah sendiri dapat didefinisakan sebagai semua buangan yang dihasilkan dari aktivitas manusia dan hewan yang berupa padatan, yang dibuang karena sudah tidak berguna atau tidak diperlukan lagi (Tchobanoglous, 1993).

Pengolahan sampah sendiri tidak benar bila dibuang ke sungai dimana dapat mengakibatkan pencemaran lingkungan dan bisa terjadi banjir. Di daerah perkotaan sendiri khususnya pinggiran sungai sering kali banjir yang diakibatkan oleh sampah yang menumpuk. Perlu penangan yang tepat agar masyarakat tidak membuang sampah di sungai.

\section{Masalah}

Kurangnya kesadaran akan pencemaran lingkungan membuat masyarakat sering kali membuang sampah tidak pada tempatnya ataupun tidak ada bank sampah di daearah tersebut. Sering kali para oknum yang tidak bertanggung jawab membuang sampah di sungai, dimana sering terjadi di daerah bantaran sungai yang ditinggali oleh masyarakat. 


\section{Tinjauan Pustaka}

(Tangguh Perdana Putra, 2016), ANALISIS PERILAKU MASYARAKAT BANTARAN SUNGAI MARTAPURA DALAM AKTIVITAS MEMBUANG SAMPAH RUMAH TANGGA DI KELURAHAN BASIRIH KECAMATAN BANJARMASIN BARAT. Berisi tentang analisis perilaku masyarakat yang membuang sampah di sungai. Dari jurnal tersebut memiliki kesamaan yaitu tentang masyarakat yang membuang sampah ke sungai.

(Indrawati, 2011), Upaya Pengendalian Pencemaran Sungai yang diakibatkan oleh Sampah. Berisi tentang upaya pengendalian pencemaran sampah. Jurnal tersebut memiliki kesamaan yaitu tentang pengendalian pencemaran sampah di sungai.

(Wheny Utariningsih), ANALISIS KERENTANAN KESEHATAN PENDUDUK PRA-BENCANA BANJIR DI KABUPATEN ACEH BARAT DAYA. Berisi tentang analisis Kesehatan penduduk. Jurnal tersebut memiliki kesamaan yaitu tentang Kesehatan masyrakat yang terancam oleh banjir

(Sujarwo, 2014), Pengelolaan Sampah organik dan anorganik. Berisi tentang pengelolaan sampah dimana buku tersaebut memeliki kesamaan yaitu tentang pengelolaan sampah.

(Yurianto, 2016), SUDAH SIAPKAH KITA MENGHADAPI BANJIR?. Berisi tentang kesiapan dalam menghadapi banjir. Buku tersebut memeiliki kesamaan yaitu membahas penyakit apa saja yang terjadi bila terkena banjir 


\section{Pembahasan}

(Azwar, 2007), menyatakan faktor-faktor yang mempengaruhi sikap masyarakat dalam aktivitas membuang sampah antara antara lain : Pengalaman Pribadi, Pengaruh Orang Lain yang Dianggap Penting, Pengaruh Kebudayaan, Media Massa, Lembaga Pendidikan dan Lembaga Agama. Dimana masyarakat sering kali salah dengan membuang sampah di sungai. Masalah kesehatan terjadi di berbagai tempat permukiman dan di tempat umum yang terkena genangan. Banjir membawa kotoran seperti sampah, air got, atau septik tank. Kondisi ini menyebabkan bibit kuman penyakit mudah berkembang biak (Wheny Utariningsih). Pembuangan sampah di sungai mengakibatkan timbulnya beberapa penyakit seperti :

1. Diare Pada saat banjir, sumber-sumber air minum masyarakat, khususnya sumber air minum dari sumur dangkal akan banyak ikut tercemar. Di samping itu pada saat banjir biasanya akan terjadi pengungsian di mana fasilitas dan sarana serba terbatas termasuk ketersediaan air bersih. Itu semua menjadi potensial menimbulkan penyakit diare disertai penularan yang cepat.

2. Demam Berdarah Pada saat musim hujan, biasanya akan terjadi peningkatan tempat perindukan nyamuk aedes aegypti yaitu nyamuk penular penyakit demam berdarah. Hal ini dikarenakan pada saat musim hujan banyak sampah misalnya kaleng bekas, ban bekas serta tempat-tempat tertentu terisi air dan terjadi genangan untuk beberapa waktu. Genangan air itulah akhirnya menjadi tempat berkembang biaknya nyamuk tersebut. Dengan meningkatnya populasi nyamuk sebagai penular penyakit, maka risiko terjadinya penularan juga semakin meningkat.

3. Leptospirosis Penyakit leptospirosis disebabkan oleh bakteri yang disebut Leptospira sp. Penyakit ini termasuk salah satu penyakit zoonosis, karena ditularkan melalui hewan/binatang. Di Indonesia hewan penular terutama adalah tikus melalui kotoran dan air kencingnya. Pada musim hujan terutama saat terjadi banjir, maka tikus-tikus yang tinggal di liangliang tanah akan ikut keluar menyelamatkan diri. Tikus tersebut akan berkeliaran di sekitar manusia di mana kotoran dan air kencingnya akan bercampur dengan air banjir tersebut. Seseorang yang ada luka, kemudian bermain/terendam air banjir yang sudah tercampur dengan kotoran/kencing tikus yang mengandung bakteri lepstopira, maka orang tersebut potensi dapat terinfeksi dan akan jatuh menjadi sakit.

4. Infeksi Saluran Pernapasan Akut (ISPA) Infeksi Saluran Pernapasan Akut (ISPA) dapat berupa bakteri, virus dan berbagai mikroba lainnya. Gejala utama dapat berupa batuk dan demam, kalau berat dapat / mungkin disertai sesak napas, nyeri dada dll.

5. Penyakit kulit Penyakit kulit, dapat berupa infeksi, alergi atau bentuk lain pada musim banjir maka masalah utamanya adalah kebersihan yang tidak terjaga baik.

6. Penyakit saluran cerna lain Penyakit saluran cerna lain, misalnya demam tifoid. Dalam hal ini juga faktor kebersihan makanan memegang peranan penting.

7. Penurunan kondisi penderita penyakit kronik Perlu diperhatikan penurunan kondisi penderita penyakit kronik, seperti asma, TB Paru, Diabetes Melitus, Penyakit Jantung, Hipertensi, dan 
lain-lain. Hal ini terjadi karena penurunan daya tahan tubuh akibat musim hujan berkepanjangan, dan apalagi bila banjir berhari-hari

Perlu untuk pengendalian pencemaran sungai agar penyakit tersebut tidak mewabah di masyarakat. (Indrawati, 2011), Pada prinsipnya ada 2 (dua) upaya untuk menanggulangi pencemaran, yaitu secara non-teknis dan secara teknis. Penanggulangan secara non-teknis melalui suatu usaha untuk mengurangi pencemaran lingkungan dengan cara menciptakan peraturan perundangan yang dapat merencanakan, mengatur dan mengawasi segala macam bentuk kegiatan industri dan teknologi sehingga tidak terjadi pencemaran. Sedangkan penanggulangan secara teknis bersumber pada penanganan limbah secara benar termasuk perlakuan industri terhadap bahan buangannya, misalnya dengan mengubah proses, mengelola limbah atau menambah alat bantu yang dapat mengurangi pencemaran terhadap lingkungan. (Indrawati, 2011), Salah satu upaya serius yang telah dilakukan Pemerintah dalam pengendalian pencemaran air adalah melalui Program Kali Bersih (PROKASIH). Untuk pengendalian sampah sendiri dapat diawali dengan diri sendiri dengan tidak membuang sampah sembarangan serta menegur orang yang membuang sampah tidak pada tempatnya khususnya di sungai.

Pengelolaan sampah sampah yang lain yaitu dengan menerapkan $3 \mathrm{R}$ :

1. Reuse (penggunaan Kembali) yaitu menggunakan sampah-sampah tertentu yang masih memungkinkan untuk dipakai (penggunaan Kembali botol-botol bekas).

2. Reduce ( pengurangan) yaitu berusaha mengurangi segala sesuatu yang dapat menimbulkan sampah serta mengurangi sampah-sampah yang ada.

3. Reycle (daur ulang) yaitu menggunakan sampah-sampah tertentu untuk diolah menjadi barang yang lebih berguna (daur ulang sampah organik menjadi kompos atau sampah anorganik menjadi kerajinan.

\section{Kesimpulan}

Sampah yang dibuang ke sungai menyebabkan beberapa penyakit diantaranya :

1. Diare

2. Demam Berdarah.

3. Leptospirosis

4. Infeksi Saluran Pernapasan Akut (ISPA)

5. Penyakit kulit Penyakit kulit,

6. Penyakit saluran cerna lain Penyakit saluran cerna lain, misalnya demam tifoid.

7. Penurunan kondisi penderita penyakit kronik

Sampah sendiri dapat ditanggulangi dengan pengelolaan sampah yang terpadu dengan menerapkan 3R yaitu Refuse, reduce, dan reycle. Dapat pula melalaui PROKASIH atau penanggulangan secara teknis dan non teknis agar masyarakat sendiri tenang dan tidak khawatir bila terjadi banjir yang menyebabkan penyakit. 


\section{Daftar Pustaka}

Azwar, S. (2007). Sikap Manusia. Teori dan pengukurannya.

Indrawati, D. (2011). Upaya Pengendalian Pencemaran Sungai yang diakibatkan oleh Sampah, 193 200.

Sujarwo, T. W. (2014). PENGELOLAAN SAMPAH ORGANIK \& ANORGANIK. Yogyakarta:

JURUSAN PENDIDIKAN LUAR SEKOLAH FAKULTAS ILMU PENDIDIKAN UNIVERSITAS NEGERI YOGYAKARTA.

Tangguh Perdana Putra, S. A. (2016). ANALISIS PERILAKU MASYARAKAT BANTARAN SUNGAI MARTAPURA DALAM AKTIVITAS MEMBUANG SAMPAH RUMAH TANGGA , 23-25.

Tchobanoglous, G. T. (1993). Integrated Solid Waste Managemen.

Wheny Utariningsih, A. A. (n.d.). ANALISIS KERENTANAN KESEHATAN PENDUDUK PRABENCANA, 1 - 10.

Yurianto, d. A. (2016). SUDAH SIAPKAH KITA MENGHADAPI BANJIR? Jakarta: Jakarta : Kementrian Kehatan RI., 2016.

Karina, Z., \& Sodik, M. A. (2018). Pengaruh Dukungan Sosial Terhadap Kesehatan.

Lopo, Y. M., \& Sodik, M. A. (2021). GERAKAN MASYARAKAT HIDUP SEHAT BEBAS MEROKOK.

Suryani, S. I., \& Sodik, M. A. (2018). Perilaku Cuci Tangan Pakai Sabun.

Pratiwi, I. Y., \& Sodik, M. A. (2018). Dampak Positif dan Negatif Meminum Kopi.

Bura, A., \& Sodik, M. A. (2021). PENCEGAHAN DINI TERHADAP PENYAKIT TIDAK MENULAR (PTM) MELALUI GERMAS.

Awan, I., \& Sodik, M. A. (2018). Diskriminasi dan Kesehatan Mental.

M'JAI, A. B., \& Sodik, M. A. (2021). Kepercayaan Masyarakat Terhadap Pengobatan Alternatif Dan Pengobatan Medis.

Bura, A., \& Sodik, M. A. (2021). Hubungan Pendapatan Keluarga, Berat Lahir, dan Panjang Lahir Dengan Kejadian Stanting B

Dadu, F. D., \& Sodik, M. A. (2021). Pengalaman Pasien Mengalami Serangan Jantung Pertama Kali yang dirawat di Ruang $\mathrm{CICU}$.

Rohmaniyah, U., \& Sodik, M. A. (2018). CARA MUDAH DETEKSI BORAKS MENGGUNAKAN KERTAS SARING UBI JALAR UNGU (KESARING BIJU). 